40. Preston, A.P. 1968. Pruning and rootstock as factors in the production of primary branches on apple trees. J. Hort. Sci. 43:17-22.

41. Quirdan, J.D. 1978. Chemical induction of lateral branches (feathers). Acts Hort. 65:129-138.

42. Quinlan, J.D. 1981. New chemical approaches to the control of fruit tree form and size. Acts Hort. 120:95-106.

43. Quinlan, J.D. and A.P. Preston. 1973. Chemical induction of branching in nursery trees. Acts Hort. 34: 123-127,.

44. Quinlan, J.D. and A.P. Preston. 1978. The use of branching agents to replace hand pruning of young trees of Bramley's Seedling apple.. J. Hort. Sci. 53:39-43.

45. Rivalta, L., R. Quarta, G.L. Bagnara, and D. Cobianchi. 1986. Miglioramento genetico del pero presso 1'ISF di Roma. Rivista Frutti. Ortoflor 48(34):34-36.

46. Sachs, T. and K.V. Thimann. 1967. The role of auxins and cytokinins in the release of buds from dominance. Nature (London) 201:939940.

47. Shamel, A.D. and C.S. Pomeroy. 1936. Bud mutations in horticultural crops. J., Hered. 27:487-494.

48. Tobrrtt, K.R. 1985. Breeding columnar apples at East Mailing. Acts Hort. 159:63-68.
49. Tydeman, H.M. 1944. A preliminary account of experiments in breeding early and midseason dessert apples. Rpt. E. Mailing Res. Sta 1943. p. 34-42.

50. Van Oosten, H.J. 1978. Effects of initial tree quality on yield. Acts Hort. 65:123-127.

51. Van Oosten, H.J. 1981. Effects of propyl-3-t-brrtylphenoxyacetate (M\&B 25-105) on the branching of maiden apple and pear trees. Meded. Facult. Landbouw. Rijksuniv. Gent. 46:247-251.

52. Visser, T. 1973. Methods and results of mutation breeding in deciduous fruits, with special reference to the induction of compact and fruit mutations in apple. Induced mutations in vegetatively propagated plants. Intl. Atomic Energy Agency, Vienna. p. 21-33.

53. Wertheim, S.J. 1978. Manual and chemical induction of sideshoot formation in apple trees in the nursery. Scientia Hort. 9:337-345.

54. Zagaga, S. W. and M. Faust. 1983. Population analysis of vigor and growth pattern of apple seedlings with short internode parentage. J. Amer. Soc. Hort. Sci. 108:939-944.

55. Zhang, G. M., G.M. Wang, Q.Y. Zhang, W.Q. Zhang, and X.Z. Tang: 1985. Pre-selection of seedlings for spur type apples. Acta Hort. 140:63-71.

\title{
Structural Manipulation for Improved Performance in Woody Plants
}

\author{
Filiberto Loreti \\ Dipartimento di Coltivazione e Difesa delle Specie Legnose, Sezione di Coltivazioni Arboree, \\ Universitá di Pisa, Italy \\ Piero L. Pisani \\ Dipartimento di Ortoflorofrutticoltura, Universitá di Firenze, Italy
}

Physical manipulation to modify tree shape and canopy size has undergone considerable evolution since the end of the last century. In the 19th century, fruit trees were trained primarily to various geometric shapes that were influenced by esthetic considerations (Fig. 1). Scientific and socioeconomic factors have been responsible for major changes in fruit tree training in the 20th century.

Our knowledge of tree physiology has contributed greatly to understanding plant responses to pruning and training, resulting in more rational and effective training methods $(9,67)$. The shortage and costs of specialized labor have greatly influenced the evolution of pruning and training practices in horticulture. These problems have affected, to a degree, fruit production, forestry, and landscape horticulture practices. Economic factors, however, have had the greatest influence on fruit crops. Profound changes in cultural practices and particularly pruning and training techniques have resulted in improved yields, fruit quality, and reduced production costs.

Few tree crop species are cultivated without any pruning and/or training. Variations in framework and small crown size are achieved through genetic manipulation, pruning, and other cultural techniques, such as rootstock, increased tree density, and the application of growth regulators. Specific pruning techniques and training methods to position tree framework and branches in space are discussed in this paper.

\section{Physiological aspects of pruning}

Correct manipulation of tree shape requires an understanding of the natural growth habit of a species and sometimes even the cultivar (43). Growth control often depends on the interaction between environmental and genetic factors. Environmental factors include photoperiod, light intensity, temperature, moisture supply, and soil fertility. Genetic factors influence vigor and photo-morphogenic and gravimorphic reactions,

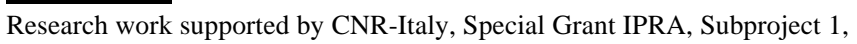
paper no. 1160.
The factors of greatest importance are the shoot/root interactions; these determine canopy size and apical dominance and its control, which, in turn, influence tree shape. The physiological basis for apical dominance and control is not fully understood, but is thought to involve a complex hormonal balance involving nutrient and gravitational influences.

An effort to relate the concepts of hormonal action and nutritional factors to apical dominance has led to the concept of mobilization, or directed translocation, as a control of lateral-bud growth. In this context, major roles are attributed to auxin transport, nutrient availability, and cytokinin level in relation to apical dominance $(1,18$, $42,72-74,78,79)$. Some authors $(19,40,44)$ consider that apical dominance and control are reciprocally related in that a plant that has strong apical dominance of lateral buds on current season's shoots has weak apical control of those buds and the shoots that develop from them the following year. Conversely, plants that have weak apical dominance of currently formed buds have strong control over the growth of lateral shoots.

Species that are characterized by strong apical dominance and weak control, such as apple, tend to assume a decurrent habit, while those with weak apical dominance and strong apical control, such as Liquidambar styraciflua L., develop an excurrent crown (Fig. 2) $(19,40,44)$. Even plants of one species do not always fit into one specific growth habit category, but often range between the two extremes. Factors affecting the expression of apical dominance and control include tree vigor, nutrient supply, crop density, and light (44).

The physiological principles of apical dominance and control have been used to obtain more uniformly branched central leaders in apple and pear cultivars. They have limited feathering (branching) ability due to strong apical dominance. Branching in these cultivars was achieved by maintaining an intact central leader in early spring, then by removing its terminal section when the last four to six shoots that were formed were 0.10 to $0.15 \mathrm{~m}$ long (Fig. 3). This practice encourages lateral bud break and shoot development in the lowermiddle region of the central leader. 


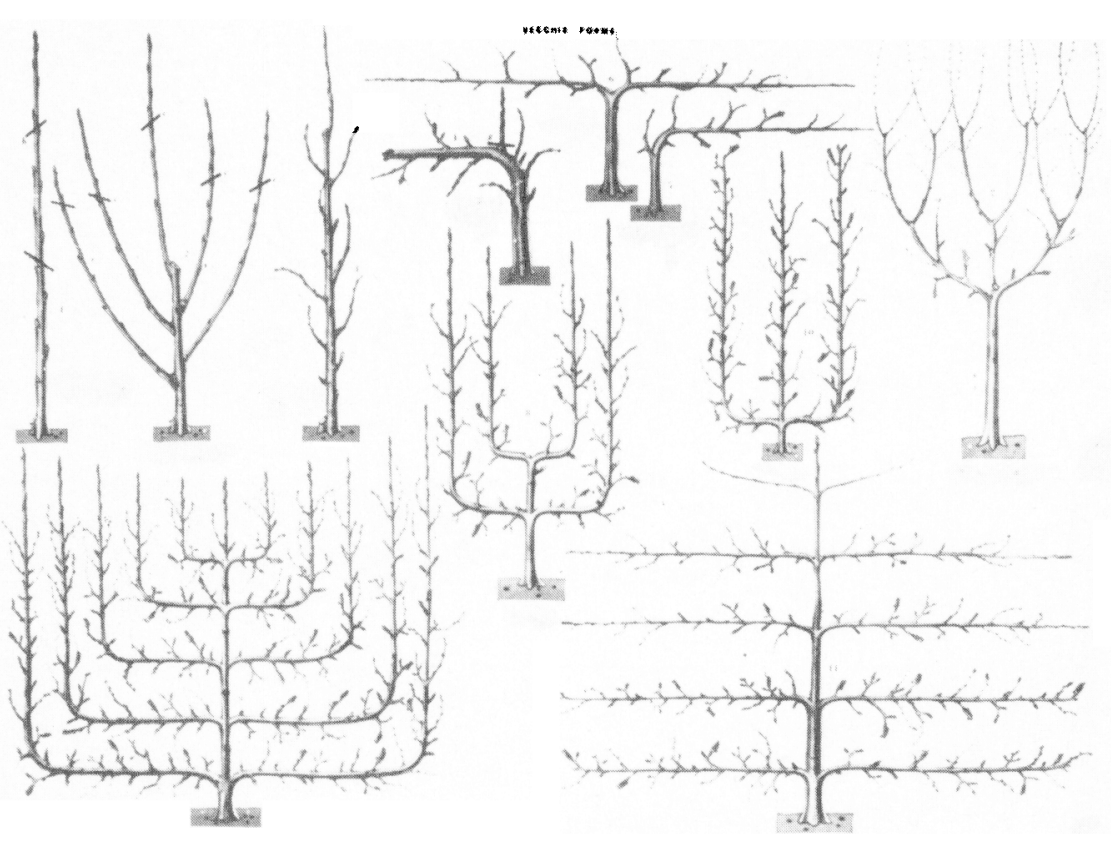

Fig. 1. Old training systems with structure strictly geometric.

On 1-year-old leaders of trees having strong apical dominance, the angle of attachment of the emerging laterals increases,.from tip to base (89). Also, the angle of attachment of a branch increases with age as does its angle of growth so that it becomes more horizontal, and in some cases, finally assumes a drooping position (19, $44,54)$. The degree to which angles of attachment are affected determines branch orientation and tree form.

The previously described pruning techniques tend to increase crotch angles. The more horizontally growing branches are not as vigorous as they would have been, thereby improving branch size relative to that of the trunk. These characteristics lead to structurally stronger

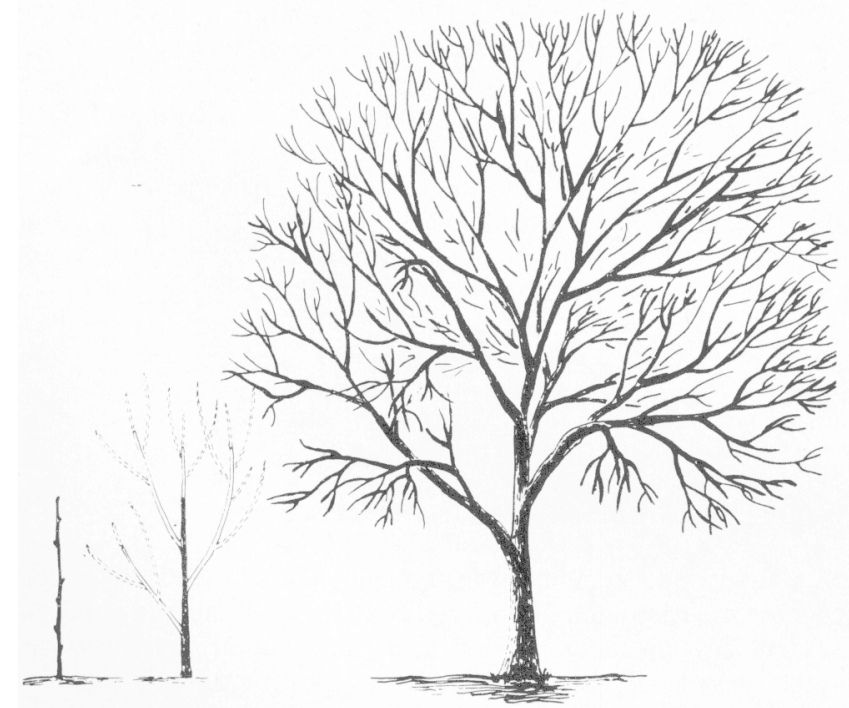

Fig. 2a. A typical decurrent tree, such as ash, after on $($ left), three (center), and many years (right). The terminal bud exerts strong apical dominance usually preventing lower buds growing during the first season, but the terminal shoot usually is outgrown in succeeding years. trees (44). This is particularly useful in "apple-spur" cultivars that have strong apical dominance and weak control, which results in poor branching on the central leader and narrow-angled branch crotches.

According to Champagnat $(20,21)$ and others $(22,27)$ the vegetative habit of plants falls into two distinguishable, opposite forms, acrotonic and basitonic. The acrotonic habit is characterized by a concentration of branches on the distal part of the vegetative axis, such as apple, giving rise to a tree, whereas the basitonic habit is characterized by concentrated branches in the proximal region of the main axis, such as olive, which develops a low-branched and

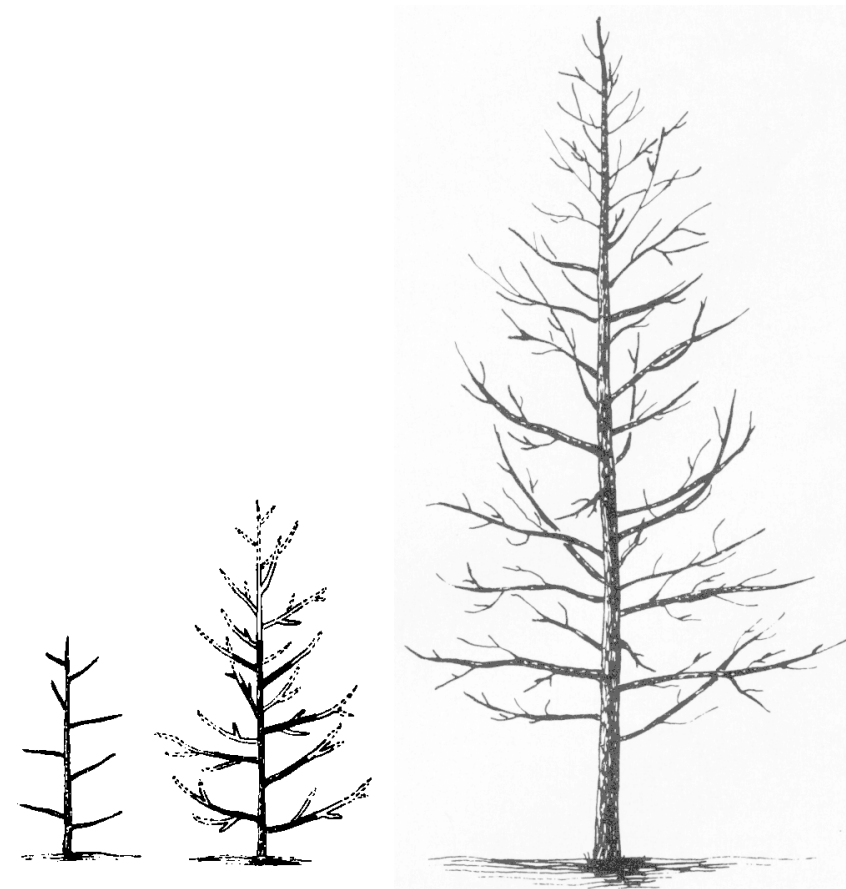

Fig. 2b. A typical excurrent tree, such as liquidambar, after one (left), three (center), and many years (right). The terminal has weak dominance but strongly controls growth, usually outgrowing and subduing the branches below (not to scale; from ref. 44). 


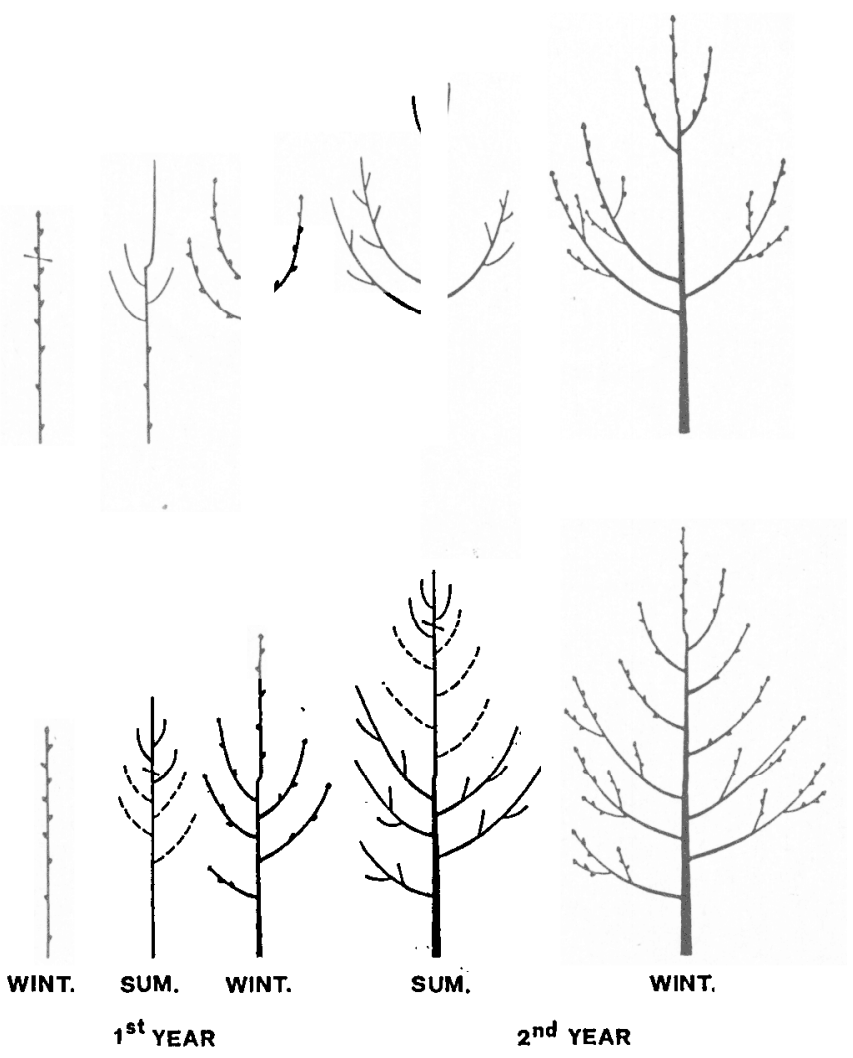

Fig. 3. Effect of heading-back of maiden trees (top) and summer pruning (bottom) on growth of laterals on apple varieties with strong apical dominance, such as 'Starking Delicious' and 'Gravenstein'.

bushy plant. Intermediate shapes exist between the two categories depending on species and cultivar; mesotonic would be an intermediate form.

In fruit plants, knowledge of the physiological aspects determining natural tree shape is important in selecting training systems and pruning techniques that result in trees with maximum yield potentials. Since many fruit species have the acrotonic habit, it is important to modify the vegetative habit of these species, usually by bending the axis. Bending the vegetative axis results in a more uniform distribution of vegetation along the shoot or branch, as is evident in the Italian "palmette" system, which has oblique branches. This training system is used primarily for apple, pear, and peach. Training these species to the palmette results in a switch of their vegetation gradient from the acrotonic to a mesotonic type (Fig. 4).

Shoot or branch bending as a physiological principle of growth control is useful in training acrotonic species. Training systems such as the palmette, however, are not applicable with basitonic species. Olive trees trained tothepalmette show stronger basitony with a heavy concentration of vegetation in the basal branch and trunk area (Fig. 4) (45, 83).

These interactions are involved in the development of training systems for fruit trees. This knowledge was applied in developing the "free spindle", attaining system for peach(11-14). Peach has moderate apical dominance that is overcome in vigorous shoots. It also concentrates branching in the distal portion of vigorous shoots (acrotonic). Therefore, a truncated-cone-shaped canopy is developed by: a) not. reducing the length of the central leader during training and b) summer pruning the vigorous lower branches to reduce their length and number (Fig. 5). The vigorous growth of the lower branches is thereby kept under control.

Increased productivity might be achieved through late-spring/earlysummer pruning. Particularly interesting are the results obtained in apple and pear by heading back the vigorous shoots of the distal branch regions (36). This gave controlled shoot development and stimulated flower bud formation. The same was found in cherry trees when shoots were reduced to three or four buds $(3,10)$.
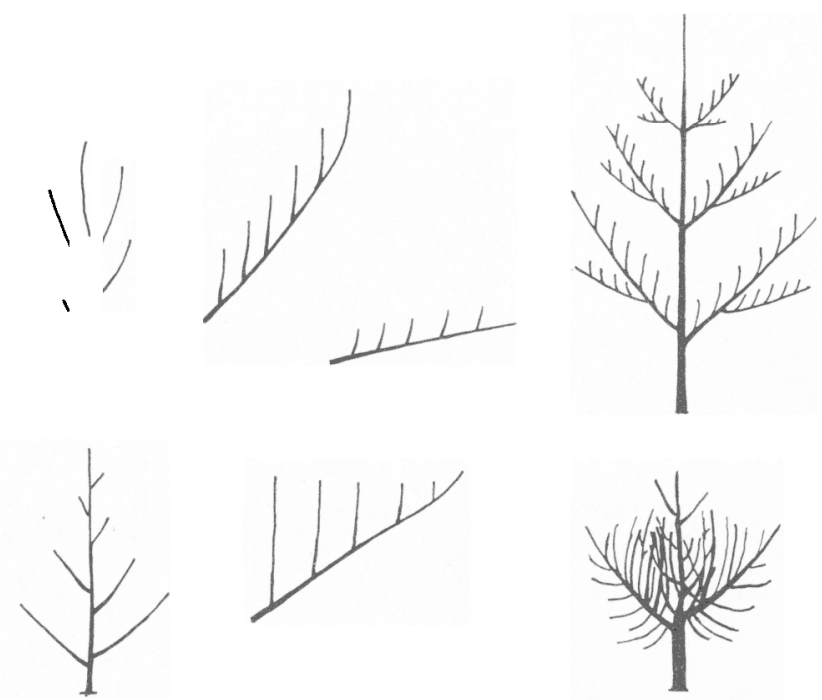

Fig. 4. Effect of branch bending of species with acrotony(top) and basitony (bottom) trained to palmette.

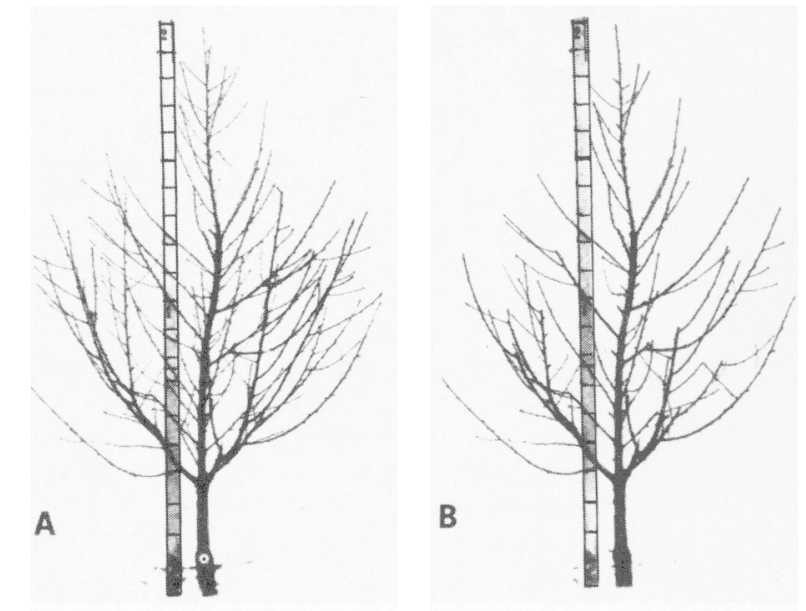

Fig. 5. Young peach tree trained to free spindle(A) before pruning, (B) after pruning. Stakes are $2 \mathrm{~m}$ tall(from ref. 12).

Cutting back above a flower cluster or complete shoot removal of growing shoots distal to the flower cluster positively influences fruit set in some pear cultivars $(56,62,80)$. Modifications of the hormonal and nutrient balance controlling flower induction and fruit set are thought to be responsible for this response.

Another important aim of tree structure modification is to maximize light interception by the trees, which results in regulation of light distribution within the canopy. The degree of light interception and the portion of the canopy that is illuminated are key factors in orchard productivity. Computer modelling has shown that in highdensity plantings leaf area index is $>1$, maximum production of high quality fruit is largely related to tree size and placement in the orchard (Table 1) $(7,37,47-49,55,61,70)$.

\section{Training and pruning to develop tree structure}

The modern concept of physical manipulation of trees to develop tree structure of pomological crops consists essentially of directing and containing the natural growth of trees to maximize productivity. On the other hand, for ornamental, the aim is primarily esthetic, i.e., to enhance tree performance and function as safe elements in the landscape. Since the desired goals to be achieved through pruning of pomological and landscape plants differ, the two will be discussed separately. 
Table 1. Growth and cropping of 'Cox Orange Pippin'/M26 apple trees in response to shading.

\begin{tabular}{lcccc}
\hline \hline & \multicolumn{4}{c}{ Light level $(\%)^{2}$} \\
\cline { 2 - 5 } \multicolumn{1}{c}{ Variable } & 100 & 37 & 25 & 11 \\
\hline Girth increment $\left(\mathrm{cm}^{2}\right)$ & 61 & 43 & 43 & 25 \\
Fruit bud clusters/tree & 159 & 96 & 69 & 26 \\
Fruits harvested/tree & 151 & 74 & 51 & 6.0 \\
Yield/tree $(\mathrm{kg})$ & 17.6 & 8.0 & 4.7 & 0.6 \\
\% of fruits $>1 / 4$ red & 47 & 30 & 16 & 13 \\
\hline
\end{tabular}

'Percentage of daylight inside a shaded area but above canopy. Data obtained from ref. 47

\section{Fruit species}

Pruning, an old tradition in fruit culture, has undergone profound evolution in recent decades (5). Until recently, pomologists grew large trees that were meticulously and severely pruned. Today, trees of reduced size are desired, which requires moderate amounts of pruning that is based on physiological principles. In Europe, particularly Italy, three evolutionary stages in tree training have been recognized based on shape and volume: a) the large or medium size vase or pyramidal shape, b) flattened shapes, and c) shapes suitable for high density planting. These changes in tree training were made possible by the availability of dwarfing and semi-dwarfing rootstock, spur-type, compact cultivars (in temperate crops), and to some extent a more rational use of cultural techniques (88).

In the past, the development and maintenance of shapes (volumes) were obtained by cuts that shortened branches and shoots and/or by bending branches and leaders to obtain a framework inspired by rigid geometric forms. In fact, in the vase and pyramid shapes, which were popular training systems at one time, the framework was formed by branches of every order and type distributed and manipulated so that there was nearly complete use of light and space. Pruning procedures were time-consuming and required much hand labor to bring the trees into full production. Maintenance pruning, to keep the tree within manageable size and shape, to reduce "thinning out" of the lower canopy region, and to maintain satisfactory productivity in the early years of the orchard were demanding and laborious.

Later training systems were void of rigid geometrical structures and used the natural vegetative and fruiting habit of the tree by avoiding or reducing heading-back pruning cuts. The reduction in branch bending coupled with the introduction of dwarfing rootstock and spur-type cultivars resulted in reduced tree size and the attainment, in a shorter period, of a balance between vegetative and productive activity, earlier bearing, and increased yields. Furthermore, high density planting systems of small trees facilitate and simplify practices such as thinning, harvesting, and pruning.

In species where dwarfing rootstock are not available and/or soil conditions are conducive to high vegetative growth, the maintenance of small trees has been obtained in several fruit species by root pruning. When root-pruned, the growth rate of the above-ground parts of a plant are modified to restore root/shoot ratios, Consequently, a redistribution of growth in favor of the root occurs and relative shoot growth is reduced. Thus, root pruning might be used as a tool to control plant size, especially where cultivars are grafted on vigorous rootstock $(2,38,41,75,76,87)$. This technique is used in ornamental and forest nurseries since it encourages the formation of a compact root system, thus reducing mortality in transplanting $(28,69)$.

Training trees to flattened shapes has undergone extensive evolution. Old and sophisticated training systems, such as the early cordon and chandelier systems, have given way to systems such as the Lepage and Bouche Thomas, and Drapeau Marchand, adopted mostly by French fruit growers. The Italian palmette, a contemporary flat-shaped system that allows for good exposure of foliage to light and facilitates mechanical harvesting, thinning, and pruning now is used in Italy. This training system was developed by heading back the central leader and bending the lateral branches, as in the oblique palmette (Fig. 6).

Recently, several innovations have been made to this system that have resulted in the free palmette. This training system begins with intact maiden trees, which may or may not have feathers (branches). Usually, the first-year trees are allowed to grow freely with summer pruning kept to a minimum. During the second year, the framework is developed by slight branch bending and a minimum of pruning. This system has resulted in an increase in planting density, earlier cropping, faster development of the final framework, and consistent reduction of hand labor.

The application of physiological principles regulating apical dominance, vegetative gradients, and pruning responses are responsible for the development of the free palmatte. The shortage of specialized hand labor and its costs have made mechanical pruning an economic necessity for some species. The control of tree height and canopy volume are attained with mechanical pruning.

Mechanical pruning is adapted more easily to. flattened shapes than to others that occupy a greater volume and that, if mechanically pruned, would require corrective hand pruning. The introduction of mechanical pruning in tree fruits has led to a shift to hedgerow systems pruned with a sickle-bar mower. These mowers are used to "top" the hedgerow to the desired height and-to taper its sides $(6,8,25,29,30,46,59,60,68,81,82)$.

Further progress in tree training has been made with the introduction of new systems that use the space allotted in high density plantings more efficiently. Shapes, such as the slender spindle, central leader, fruit wall, and bed systems, although different from one another, have in common the requirements of trees of reduced size, simple framework, reduced planting distance, minimum spring and summer pruning, and pruning in winter to reduce lateral branch length. Short tree height is maintained to facilitate cultural practices from the ground. The slender spindle for apple and the free spindle for peach have had much success in north-central Europe and are now common in several Italian fruit growing areas. The slender spindle is formed by a central leader with branches of decreasing length towards the apex so that the canopy is shaped into a cone. These advanced training systems are simple and provide for high light interception and penetration into the canopy.

The "meadow orchard", an ultra-high-density system was developed for apples in England $(65,66)$. Pruning and a skeletal structure are totally eliminated in this system. The trees are cut a few centimeters above ground following planting. The tree is allowed to grow a year for flower bud formation. Fruit appear the following year and the entire tree is cut a few centimeters above the ground and the process is repeated. This system has proven

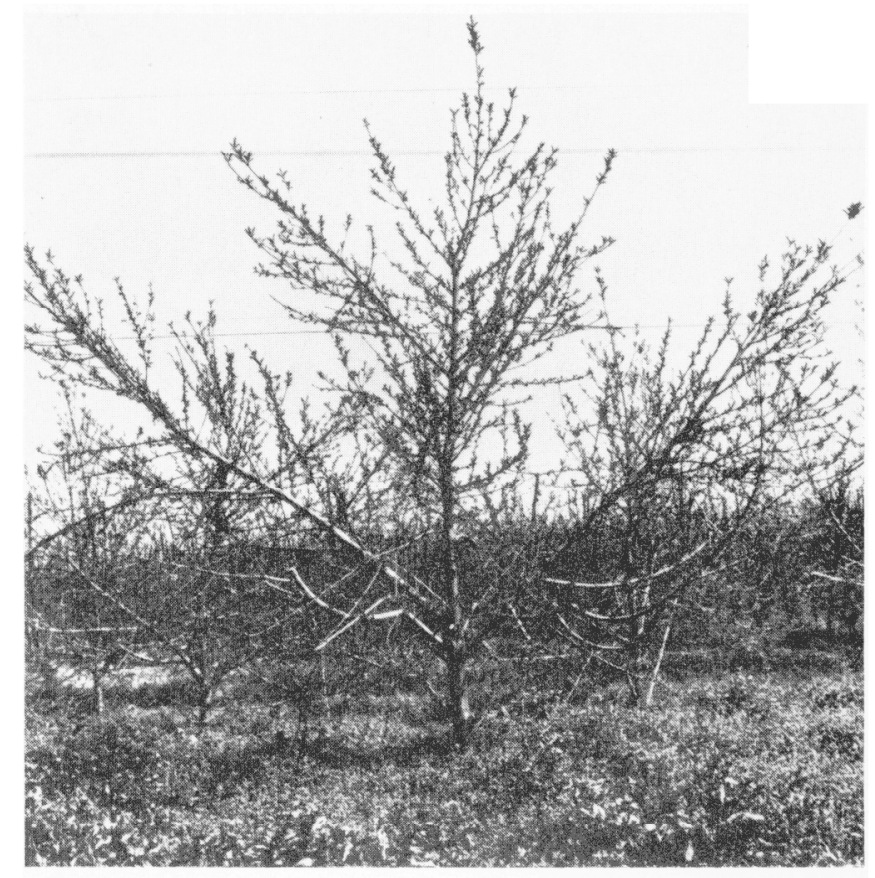

Fig. 6. Young peach tree trained to oblique palmette. 
feasible for peach as far as commercial field and protected cultivation is concerned $(15-17,26,31-35,63,64,84)$. With the peach, pruning and harvesting is an annual practice.

\section{Woody species for landscape and forest areas}

Since the many species used in landscapes and forests have diverse uses, it is difficult to examine thoroughly all aspects of their training. Thus only those aspects of major interest will be dealt with here.

Management of landscapes, like fruit growing, has undergone profound modifications in recent decades. The quality and costs of maintenance and hand labor are major problems. Physiological and technical principles applied in fruit tree pruning might be extended to forest and landscape trees, with slight modifications depending upon the intended use of the plants.'

Several contradictions arise in the application of pruning techniques to landscape trees. On one hand, there is the extensive and meticulous labor required of topiary used in historical gardens, and on the other, there are neglected trees on which little pruning has been done or which have been overpruned or pruned without reason. This is frequently the case of trees grown along highways, roads, and avenues. In this case, the primary aim is to control canopy size and is often achieved by drastic dehorning of primary and secondary branches $(23,24)$.

This practice results in responses by the tree that are difficult to control, in the need for further pruning, and in. a lack of wellbalanced and pleasing form. Moreover, repeated pruning cuts provide for entrance of wood-rotting organisms that can seriously injure a tree. This problem is common in plane trees (Platanus $\times$ acerifolia Wind.), a species widely planted in many cities. Pruning to achieve a canopy. shape that is like its natural habit of growth would be a solution from an esthetic and economic point of view. This could be obtained by thinning out large branches and shortening small ones at short intervals. These operations could be done using elevated platforms equipped with pneumatic pruning shears and saws.

Substantially different solutions could be adopted in the creation of trees for new parks. Crown shaping of trees should begin at the seedling stage in the nursery where they could be trained by pruning, combined with high density plantings to achieve the desired shape.

The ideal type of tree for city avenues and roads is one having a pyramid-type canopy with a dominant central leader and lateral branches starting above four meters (4). To obtain this shape, suit'able pruning must be carried out in the nursery to favor the formation of an undivided trunk that is uniformly covered with branches that decrease in length towards the top. The pruning principles used here are the same as the ones for cone-shaped fruit trees.

A tree with branches well spaced from near the ground upward can be obtained by allowing sufficient planting distances in the nursery, and by cutting back the central leader in order to force branches along the trunk (23).

Species that are grown for several years in the nursery to produce large trees undergo several transplanting to ensure a dense root system and normal plant development. The trees are replanted at greater distances at each transplanting. Pruning to develop structure and shape is done each year (Fig. 7).

The type and amount of pruning required on established trees depends on their use in the landscape and whether they grow in open spaces, such as woods and parks, or in confined spaces, such as playgrounds or gardens. For open spaces, pruning is kept to a minimum and confined to corrective pruning. These trees assume and keep a natural shape, which is the result of their vegetative habit, their environment, and available space. In the past, trees planted in confined areas were cut more or less drastically to control size and form rigid geometric patterns. Recently, for economic and esthetic reasons, trees are trained to more natural shapes with minimum pruning. It is important that the training consider tree use and space limitations. Flowering trees and ornamental fruit plants should be treated similarly as fruit crop species to enhance flower and fruit production. However, mature, spring-flowering plants should be pruned after bloom.

In the case of forest trees for wood production, pruning is used exclusively to improve trunk characteristics. Tree structure, in this case, is regulated by planting density, since increased density favors less tapered trunks with small branches $(54,57,58)$. Fire danger is reduced by removing the lower branches that are not shaded out. A pruning method that can be defined as indirect, has been proposed to obtain a "knot-free" trunk. Lateral buds are rubbed off, young branches removed, or lateral buds kept from growing by binding the trunk $(71,77,86)$.

Generally, pruning is performed in species used for intensive wood production and those, such as conifers, that do not prune themselves naturally but may retain lower branches for many years. Pruning consists of the progressive removal of the basal and medial branches to obtain knot-free lumber and a cylindrical trunk (50-52, 85); such an operation can also be made mechanically (39). It should be performed on the basal part of the trunk and not exceed $30 \%$ to $40 \%$ of the height. Basal branches with few leaves should also be removed, since they do not contribute growth in trunk girth (53).

\section{Conclusions}

Physical manipulation of tree structure has experienced much
3 or more YEARS

\section{1-3 YEARS}

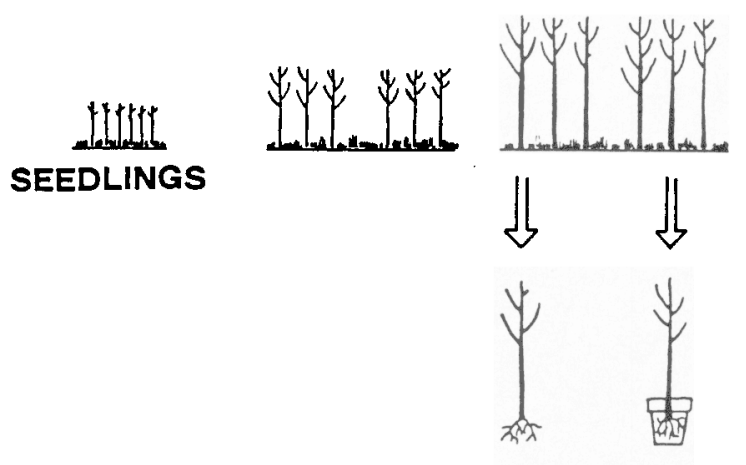

2-5 YEARS

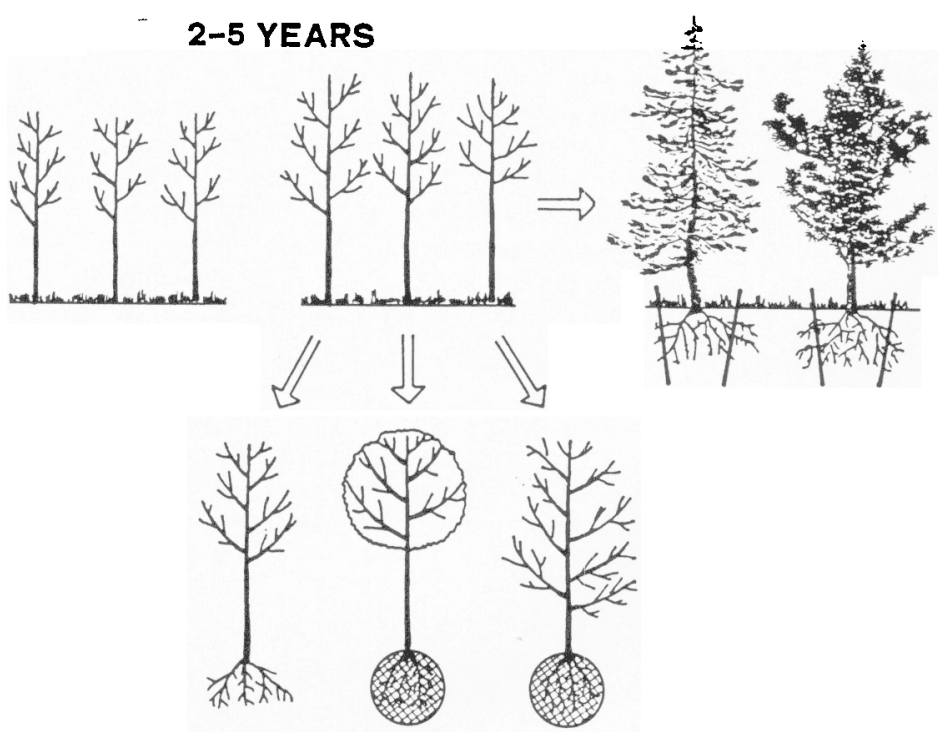

Pig. 7. Sequence of nursery production of various types of ornamental trees. 
evolution in the last several decades. Pruning, an integral part of fruit crop culture, is of fundamental importance for improving crop quantity and quality, and for adapting tree structure to modern cultural practices to reduce the amount of hand labor required. The pruning techniques used are related to the application of physiological principles. These factors, although relevant for urban landscapes, have not influenced manipulation of the shape of ornamental trees to the same extent as they have for fruit trees. Pruning is more limited in forestry and does not require hand labor at the same skill level.

New pruning strategies have recently been developed primarily with fruit trees, which use training systems, such as the flattened hedge row, which are easily adapted to mechanical pruning. Although complete mechanization, which has been proposed in the meadow orchard, does not seem feasible, further progress can be expected by improving efficiency of mechanized pruning systems. Less progress has been made in the mechanization of pruning forest and landscape trees; however, equipment to position laborers and to assist in making the cuts should continue to improve.

Genetic manipulations have great potential to alter tree form. Compact cultivars and new rootstock to control vigor and modify the vegetative habit of a tree could be of great importance in extending and applying modern techniques to new fruit and landscape species.

\section{Literature Cited}

1. Aggio, F., C. Giulivo, and A. Ramina. 1976. Observation on feathers formation in peach trees. 3rd contribution. Riv. Ortoflorofrutt. Ital. 60(1):33-39.

2. Alexander, D.M. and D.H. Maggs. 1971. Growth responses of sweet orange seedlings to shoot and root pruning. Ann. Bet. 35: 109-115.

3. Alibert, J.P. 1982. Risultati di una sperimentazione in differenti sistemi di allevamento del ciliegio realizzati in Francia. Atti Giornate Veronesi: "Il ciliegio", Verona, Feb. p. 69-82.

4. Bagnaresi, U. and A. Chiusoli. 1985. Bosco e Città Verde pubblico $0: 49-53 ; 64-66$.

5. Baldini, E. 1974. Trends in training systems for deciduous trees. XIX Intl. Hort. Congr., Warszwa. p. 115-124.

6. Baldini, E. and C. Intrieri. 1978. Meccanizzazione integrale dells vendemmia e dells potatura in vigneti allevati a doppia spalliera tipo GDC. L'Inf. Agrar. 20:1721-1727.

7. Baldini, E. and C. Intrieri. 1985. Indagini comparative sull'energia radiante disponibile in alcune forme di allevanmento dells vite. L'Inf. Agrar. 32:49-58.

8. Baldini, E., C. Intrieri, and B. Marangoni. 1976. Potatura meccanica: una nuova prospettiva per la viticoltura. L'Inf. Agrar. 31:23,56323,569 .

9. Barden, J.A. and R.P. Marini. 1984. Summer and dormant pruning of apple. A four year summary. Acta Hort. 146:263-268.

10. Bargioni,.G. 1982. Alcuni aspetti di tecnica colturale del ciliegio. Atti Giornate Frutt. Veronesi; "Il ciliegio", Verona, Feb.:55-67.

11. Bargioni, G., F. Loreti, and P.L. Pisani. 1979. Osservazioni sulla coltivazione del pesco ad elevate densità di piantagione-Riv. Ortoflorofrutt. Ital. 2:147-159.

12. Bargioni, G., F. Loreti, and P.L. Pisani. 1983. Performance of peach and nectarine in high density system in Italy. HortScience 18:143146.

13. Bargioni, G., F. Loreti, and P.L. Pisani. 1984. Ricerche sulle densità di piantagione del pesco. Riv. Ortoflorofrutt. Ital. 5:423-432.

14. Bargioni, G., F. Loreti, and P.L. Pisani. 1985. Ten years of research on peach and nectarine in a high density system in the Verona area. Acts Hort. 173:299-309.

15. Bellini, E., A. Cimato, and P.L. Mariotti. 1979. Frutteti prato di nettarine in coltura protetta. L'Inf. Agrar. 36:7253-7259.

16. Bellini, E., A. Cimato, and P.L. Mariotti. 1984. Sei anni di osservazioni sul pescheto prato di nettarine autoradicate in coltura protetta Atti Conv. Intl. Pesco, Verona, Ravenna, Campania, p. 391-401.

17. Bellini, E. and O. Musso. 1984. Prime osservazioni sad peschetoprato in coltura protteta in Sicilia. Poster presentato al "Convegno Internzionale sul Pesco", Verona, Ravenna, Campania, 9-14 July 1984.

18. Boniolo, A., A. Ramina, and F. Pimpini. 1976. Assimilate distribution and apical dominance inPisum sativum L. Riv. Ortoflorofrutt. Ital. 60(4):213-223.

19. Brown, C.L. 1971. Growth and form, p. 125-167. In: M.H. Zimmermann (cd.). Tree structure and function. Springer-Verlag, Berlin.
20. Champagnat, P. 1954. Les corrélation sur la rameau d'un an des végétaux ligneux. Phyton 4:1-101.

21. Champagnat, P. 1965. Quelques caractères de la ramification du rameau d'un an des végétaux legneux. 96th Congr. Soc. Pomol. France:833.

22. Champagnat, P. and J. Crabbé. 1974. Morphogenetical constraint and training of fruit trees. XIX Intl. Hort. Congr. Warsaw, 2:125136.

23. Chiusoli, A. 1982. Gli scotennatori degli alberi. L'Inf. Agrar. XXXVIII $35: 22,395-22,398$.

24. Chiusoli, A. 1982. La potatura degli alberi ornamental. L'Inf. Agrar. XXXVIII. 45:23,285-23,290.

25. Collalto, G. di and P.L. Pisani. 1983. Realtà e prospettive nella meccanizzazione integrale del vigneto a controspalliera. Vignevini X. 9:1926.

26. Couvillon, G.A. and A. Erez. 1982. Production potential and tree regeneration in a peach meadow orchard in the Southeastern United States. Compact Fruit Tree 15:166-175.

27. Crabbè, J. 1981. The interference of bud dormancy in the morphogenesis of tree and shrubs. Acts Hort. 120:167-173.

28. Davidson, H. and R. Mecklenburg. 1981. Nursery management and culture. Prentice Hall, Englewood Cliffs, N.J.

29. Emerson, F.H. and R.A. Hayden. 1980. The effect of training and pruning system on the long term yield of apple. Compact Fruit Tree 14:85-89.

30. Emerson, F.H. and R.A. Hayden. 1984. Control of tree vigor by mechanical hedging. Acta Hort. 146:231-234.

31. Erez, A. 1976. Meadow orchard for the peach. Scientia Hort. 5:4348.

32. Erez, A. 1978. Peach meadow orchard as developed in Israel: concept and practice. Compact Fruit Tree 11:13-16.

33. Erez, A. 1981. The fresh marked peach meadow orchard: the mechanized and the intensive high-yield system. Acta Hort. 114:285-291.

34. Erez, A. 1982. Peach meadow orchard: two feasible systems. HortScience 17:138-142.

35. Erez, A. 1984. La coltivazione del pesco con il metodo del frutteto prato. Atti "Convegno Internazionale del Pesco". Verona, Ravenna, Campania, p. 9-14.

36. Errani, A. 1982. Recenti acquisizioni sulle forme di allevamento e sulle tecniche di potatura del melo nel Veronese. Atti Conv. "Nuovi orientamenti per la coltura del me lo nel Veronese" Verona, 25 Nov., p. 99-124.

37. Ferree, D.C. 1981. Canopy development, light and spray penetration in Golden Delicious trees in four management systems. Acta Hort 114:91-97.

38. Ferree, D.C. and D. Geisler. 1984. Root pruning as a means of size control. Acta Hort. 146:269-275.

39. Flammarion, J.P. 1984. Elagage au robot des résineux à croissance rapide. Revue For. Franc. 4:343-350.

40. Ford, E.D. 1985. Branching, crown structure and the control of timber production. In: M.G.R. Cannell and J.E. Jackson (eds.). Attributes of trees as crop plants. NERC. p. 228-252.

41. Geisler, D. and D.C. Ferree. 1984. Response of plant to root pruning. Hort. Rev. 6:155-188.

42. Giulivo, C. and A. Ramina. 1974. Osservazioini sulla formazione dei germogli anticipate sad pesco. 11 Contribute, Riv. Ortoflorofrutt. Ital. 3:170-176.

43. Hallé, F., R.A.A. Oldeman, and P.B. Tomlinson. 1978. Tropical trees and forests: an architectural analysis. Springer-Verlag, Berlin.

44. Harris, R.W. 1983. Arboriculture: Care of trees, shrubs, and vines in the landscape. Prentice Hall, Englewood Cliffs, N.J.

45. Jacoboni, N. 1962. Forme di allevanmento dell'olivo. Atti I $\mathrm{I}^{\circ}$ Convegno Nazionale Olivicolo-Oleario, Spoleto, 1-3 giugno: 40-69.

46. Intrieri, C., G. Collako di, A. Lavezzi, L. Lisa, P.L. Pisani, O. Silvestroni, and G. Stefanelli. 1981. Meccanizzazione dei vigneti a "doppia cortina". P.F. Mecc. Race. Potat. Vigneti uva da vine, CNR, Quad. Sint. 16:41-77.

47. Jackson, J.E. 1980. Light interception and utilization by orchard systems. Hort. Rev. 2:208-267.

48. Jackson, J.E. 1981. Theory of light interception by orchard and a modelling approach to optimizing orchard design. Acta Hort. 114:6979 .

49. Jackson, J.E. 1985. Future fruit orchard design: economics and biology. In: M.G.R. Cannel and J.E. Jackson (eds. ). Attributes of trees as crop plants, NERC.:441-459.

50. Jung, H.E. and P.J. Kramer. 1952. The effect of pruning on the height and diameter growth of loblolly pine. J. For. 50:474-479.

51. Keller, R. 1982. A propos de l'élagage des resineux. For. de France et Action For. 251: 19-29.

52. Keller, R. and E. Thiercelin. 1974. L'élagage des plantations d'epicea 
commun et de douglas. Rev. for. France 4:289-302.

53. Kozlowski, T.T. 1971. Growth and development of trees, vol. 2., Academic, New York.

54. Kramer, P.J. and T.T. Kozlowski. 1979. Physiology of woody plants. Academic, New York.

55. Lakso, A.N. 1981. Aspects of canopy photosynthesis and productivity in the apple tree. Acta Hort. 144:100-109.

56. Lalatta, F. and V. Salaroli. 1970. Prove sulla potatura di produzione del pesco "Abate Fetél”. Ann. Inst. Sperim. Fruttic. p. 165-172.

57. Larson, P.R. 1963. Stem form and silviculture. Proc. Soc. Amer: For., p. 103-107.

58. Larson, P.R. 1963. Stem form development in forest trees. For. Sci. Monogr. 5.

59. Loreti, F. 1970. Orientamenti per una meccanizzazione integrale dells potatura degli alberi da frutto. Frutticoltura 6:17-37.

60. Loreti, F. and R. Guerriero. 1978. Evoluzione delle forme di allevamento e distanze di impianto. L'Italia Agr. 10:75-91.

61. Loreti, F., S. Morini, and D. Stefanelli. 1981. Some observations on sunlight, interception and distribution by peach trees at different planing densities. Acta Hort. 114:89.

62. Laeti, F., S. Natali. 1982. Il pero, cap. 4. Potatura, REDA, Roma, p. 90-117.

63. Loreti, F., G. Scalabrelli, and O. Musso. 1986. Ricerche preliminary sul l' impiego del paclobutrazolo nel pesco in coltura protetta. Att $18^{\circ}$ Conv. peschicolo, Cesena, 3 Amaggio. p. 183-194.

64. Loreti, F., G. Scalabrelli, and O. Musso. Ricerche sul comportamento vegetative e produttivo del pesco in colture protette. 4:49-55.

65. LuckWill, L.C. 1978. Meadow orchards and fruit walls. Acta Hort 65:237-243.

66. Luckwill, L.C. and R.D. Child. 1973. The meadow orchard-a new concept of apple production based on growth regulators. Acta Hort. 34(1):213-220

67. Mika, A. 1986. Physiological responses of fruit trees to pruning. Hort. Rev. 8:337-378

68. Montevecchi, P., S. Sansavini, and L. Giunchi. 1986. La potatura meccanica del pero in rapporto alla forma di allevamento. Frutticoltura $1: 34-43$.

69. Mullin, R.D. 1966. Root pruning of nursery stock, For. Chron. 42:256264.

70. Palmer, J.W. 1981. Computed effects of spacing on light interception and distribution within hedgerow in relation to productivity. Acta Hort. 114:80-88.
71. Paul, B.H. Tree pruning by annual removal of lateral buds. J. For. 7, 44:499-501.

72. Phillips, I.D.J. 1969. Apical dominance, p. 165-202. In: M.B. Wilkins (cd.). Physiology of plant growth and development. McGraw Hill, London.

73. Ramina, A. 1969. Osservazioni sulla formazione dei germogli anticipati nel pesco: $I^{\circ}$ Contribute. Riv. Ortoflorofrutt. Ital. 53, 6:611616.

74. Ramina, A. 1976. Aspetti fisiologici dells dominanza apicale. Atti Ace. Econ. Agr. Georgofili; Vol. XXII, S. VII: 249-264.

75. Richards, D. and R.N. Rowe. 1977. Root-shoot interaction in peach: The function of the root. Ann. Bet. 41:1211-1216.

76. Richards, D. and R.N. Rowe. 1977. Effects of root restriction, root pruning and 6-benzylaminopurine on the growth of peach seedlings. Ann. Bet. 41:729-740.

77. Rowland, C.A. Jr. 1950. Early results of bud pruning on slash pine. J. For. 48:100-103.

78. Sachs, T. and K.V. Thimann. 1964. Release of lateral buds from apical dominance. Nature 29:939-940.

79. Sachs, T. and K.V. Thimann. 1967. The role of auxins and cytokinins in the release of buds from dominance. Amer. J. Bet. 54:136-144.

80. Sansavini, S. 1966. Raccorciamento delle branche e fruttificazione nella cultivar "Decana del Comizio". Frutticoltura 6, 7:467-474.

81. Sansavini, S. 1978. Mechanical pruning of fruit trees. Acta Hort. 65:183-197.

82. Sansavini, S. and L. Giunchi. 1980. Ricerche sulla potatura meccanica estiva ed invemale del pero. Riv. Ortoflorofrutt. Ital. 61:591-602.

83. Scaramuzzi, F. 1962. "Gradienti di vegetazione" e nuove forme di allevamento dell'olivo. L' Italia Agricola 7:633-640.

84. Scaramuzzi, F. and E. Bellini. 1973. 11 pesco in coltura protetta. L'Ital. Agr. 1:107-116.

85. Slabaugh, T.E. 1957. Effects of alive crown removal on the growth of red pine. J. For. 55:904-906.

86. Smith, D.M. 1962. The practice of silviculture. Wiley, New York.

87. Tonutti, P., A. Ramina, G. Costa, and R. Biasi. 1986. Effect of root pinning and SADH on vegetative growth control and cropping of apple. XXII Intl. Hort. Congress. Davis, Calif.

88. Tukey, H.B. 1978. Dwarfed fruit trees. Cornell Univ. Press. Ithaca, N.Y.

89. Verner, L. 1955. Hormone relations in the growth and training of apple trees. Univ. of Idaho, College Agr. Res. Bul. 28. 